\title{
ОСНОВНІ ВИМОГИ ДО СТРУКТУРИ ТИПОВИХ МЕДИЧНИХ ІНФОРМАЦІЙНИХ СИСТЕМ В УПРАВЛІННІ ОХОРОНОЮ ЗДОРОВ'Я
}

\author{
О. П. Мінцер, М. В. Банчук, Л. Ю. Бабінцева, І. А. Ярменчук ${ }^{1}$, С. О. Дяченко ${ }^{2}$ \\ Національна медична академія післядипломної освіти імені П. Л. Шупика; Поліклініка для вчених НАН \\ України; ${ }^{1} T O B ~ « C I E T »^{2}$
}

\begin{abstract}
В сучасних умовах розвитку охорони здоров'я для забезпечення належної якості медичної допомоги існує потреба в накопиченні й аналізі даних впродовж тривалого періоду, застосуванні електронних експертних систем. Представлена робота визначає основні принципи побудови інформаційних систем для оптимізації управління закладами охорони здоров'я, насамперед, при прийнятті рішень. Розглянуті основні завдання та вимоги до інформаційних систем на регіональному і локальному рівнях. Доведено, що типові структури медичних інформаційних систем повинні мати можливості моніторингу ризиків для пацієнтів і рішення щодо ідентифікації небезпеки для управлінців.
\end{abstract}

Ключові слова: якість медичної допомоги, медичні інформаційні системи, оптимізація управління охороною здоров'я, моніторинг ризиків, ідентифікація небезпеки.

\section{ОСНОВНЫЕ ТРЕБОВАНИЯ К СТРУКТУРЕ ТИПОВЫХ МЕДИЦИНСКИХ ИНФОРМАЦИОННЫХ СИСТЕМ В УПРАВЛЕНИИ ЗДРАВООХРАНЕНИЕМ}

О. П. Минцер, Н. В. Банчук, Л. Ю. Бабинцева, И. А. Ярменчук ${ }^{1}$, С. А. Дяченко ${ }^{2}$ Национальная медицинская академия последипломного образования имени П. Л. Шупика

Поликлиника для ученых НАН Украины'

$O O O « C I E T »^{2}$

В современных условиях развития здравоохранения для обеспечения надлежащего качества медицинской помощи существует потребность в накоплении и анализе данных на протяжении длительного периода, применении электронных экспертных систем. Представленная работа определяет основные принципы построения информационных систем для оптимизации управления учреждениями здравоохранения, прежде всего, при принятии решений. Рассмотрены основные задачи и требования к информационным системам на региональном и локальном уровнях. Доказано, что типовые структуры медицинских информационных систем должны иметь возможности мониторинга рисков для пациентов и решения относительно идентификации опасности для управленцев.

Ключевые слова: качество медицинской помощи, медицинские информационные системы, оптимизация управления здравоохранением, мониторинг рисков, идентификация опасности.

\section{BASIC REQUIREMENTS TO STRUCTURE OF TYPICAL MEDICAL INFORMATIVE SYSTEMS IN HEALTH CARE MANAGEMENT}

\author{
O. P. Mintser, M. V. Banchuk, L. Yu. Babintseva, I. A. Yarmenchuk', S. O. Diachenko² \\ National Medical Academy of Post-Graduate Education by P. L. Shupyk; Policlinic for scientists of NAS of \\ Ukraine, ${ }^{1}$ CIET, Ltd ${ }^{2}$.
}

\begin{abstract}
In modern development of health care for providing proper quality of medicare there is a necessity in accumulation and analysis of data during the long period, application of electronic and consulting models. The presented work deter mines basic principles of construction of the informative systems for optimization of management of health care establishments, first of all, at making decisions. Basic tasks and requirements to the informative systems on regional and local levels are considered. It is proven that typical structures of the medical informative systems must have possi bilities of risks monitoring for patients and decisions as to danger identification for managers.
\end{abstract}

Key words: quality of medicare, medical infor mative systems, optimization of health care management, risks monitoring, danger i d entification.

О О. П. Мінцер, М. В. Банчук, Л. Ю. Бабінцева, І. А. Ярменчук, С. О. Дяченко, 2011 
Вступ. У третьому тисячолітті світ вступив у період інформаційного суспільства, тісно пов'язаного 3 інформатизацією охорони здоров'я й освіти.

В умовах довкілля, що безперервно погіршується, людство постійно хвилює питання, пов'язане із забезпеченням здоров'я індивіда і популяції. Три основні проблеми потребують невідкладного рішення: профілактика захворювань, своєчасна діагностика патологічних процесів і надання кваліфікованої медичної допомоги. При неймовірно високих розцінках на медичне обслуговування існує необхідність створення механізму усунення непотрібних медичних послуг, але 3 наданням відповідної медичної допомоги.

Найкращим шляхом вирішення цієї проблеми було б створення ідеальних профілів хвороб і їх лікування. Необхідні відомості для подібних профілів, що дістали назву " Стандарти діагностики і лікування", можна було б отримати шляхом статистичного аналізу медичних даних у глобальній медичній інформаційній системі (МІС). Проте для ऑii створення необхідна інформатизація охорони здоров'я, прийняття єдиної концепції і відповідної інфраструктури для отримання, зберігання і обробки медичної інформації.

Абсолютно очевидно, що стратегічним завданням інформатизації охорони здоров'я України повинно стати забезпечення державної системності вирішення завдань, пов'язаних з проблемами збору, зберігання й оброблення медичної інформації, інформатизації медичної освіти, телемедичних послуг, інформаційної підтримки рішень в управлінні охороною здоров'я тощо

Безперечно, в концепції інформатизації охорони здоров'я України найважливіше місце повинні займати питання створення типової медичної інформаційної системи.

Окрім відносної незабезпеченості закладів охорони здоров'я комп'ютерною технікою, використовувані прикладні системи не дозволяють забезпечити підтримку рішень актуальних завдань як у площині управління галуззю, так і в області безпосереднього надання медичної допомоги. Спостерігається надзвичайно низький рівень нормативного та методичного забезпечення процесів інформатизації охорони здоров'я. Можна констатувати, що Україна є однією із держав 3 вкрай недостатньо розвиненою інфраструктурою на всьому пострадянському просторі.

Метою роботи $\epsilon$ визначення основних принципів побудови інформаційних систем для оптимізації управління закладами охорони здоров'я.

Матеріали та методи дослідження. Враховуючи соціальну значущість проблеми розроблення медичної інформаційної системи нами вивчено досвід створення інформаційних систем. Водночас використовували рішення, що були застосовані при побудові типової інформаційної системи лікувального закладу "Каштан" (функціонує в Полтавській міській поліклініці $\mathrm{N}^{\circ} 3$ i міській клінічній лікарні м. Полтави).

Розглядаючи основні завдання та вимоги до інформаційних систем на регіональному і локальному рівнях, слід виділити такі:

1. Однотипність технічного та комп'ютерного оснащення лікувально-профілактичних закладів (ЛІ ГУ) та створення єдиної локально-обчислювальної мережі, що об'єднує всі підрозділи ЛПУ.

2. Забезпечення функціонування інформаційної системи в усіх структурних підрозділах ЛПУ.

3. Перевірка первинної медичної інформації щодо характеристик валідності та релевантность

4. Формування необхідних документів на основі первинного збору інформації, підтримка функціонування медичного електронного паспорта пацієнта.

5. Моніторинг вартості медичних послуг, що надає ЛПУ на основі сучасних методик, котрі грунтуються на методології БЯО-груп.

6. Можливість проведення постійного навчання персоналу ЛПУ з інформаційних технологій.

7. Моделювання структурних змін ЛПУ для більш ефективного використання бюджетних коштів.

8. Проведення економіко-статистичного аналізу діяльності ЛПУ.

Одним з важливих завдань практичної охорони здоров'я $€$ оцінювання стану пацієнтів. Кількісні оцінки здоров'я (в сенсі ризиків виникнення захворювань) i зараз використовуються в деяких клінічних установах. Але порівняльні характеристики ризиків не дозволяють вирішити питання про їхню значимість і прийнятність. Це відбувається внаслідок відсутності моніторингу подій. Відповідно, процедури моніторингу стану пацієнтів повинні бути обов'язковими при конструюванні медичних інформаційних систем. Окрім того, при аналізі прийнятності ризику мають бути враховані вигоди від використання лікувальних засобів; можливість здійснення контролюючих (регулюючих) заходів з метою зменшення потенційного негативного впливу фактора ризику на здоров'я пацієнтів.

Стратегія контролю рівнів ризику передбачає заходи, що найбільше сприяють мінімізації або усуненню ризику. Такі типові заходи можуть включати обмеження впливу фактора ризику (наприклад, знижен -ня артеріального тиску, рівня холестерину) або повне усунення (припинення куріння). 
Управління ризиком є логічним продовженням оцінювання ризику та спрямоване на обгрунтування найкращих у даній ситуації рішень 3 його усунення або мінімізації, а також динамічному контролю (моніторингу) експозицій і ризиків, оцінці ефективності та коректуванню оздоровчих заходів. Керування ризиком базується на сукупності медичних i економічних оцінок отриманих величин ризику, порівняльній характеристиці можливих втрат для здоров'я, можливих витрат на реалізацію різних варіантів управлінських рішень щодо зниження ризику й тих вигід, що будуть отримані в результаті реалізації заходів (наприклад, зменшення кількості ускладнень при лікуванні тощо).

У завдання управління ризиком входить також вибір стратегії динамічного (періодичного або постійного) моніторингу експозицій і ризиків. При цьому переслідуються такі функції: контрольна (порівняння 3 гранично припустимими або прийнятними рівнями), сигнальна (швидке реагування на виникнення небезпечної ситуації), прогностична (можливість прогнозування ризиків на основі аналізу тимчасових тенденцій), інструментальна (як засіб для розпізнавання та класифікації спостережуваних явищ).

Моніторинг експозицій і ризиків, заснований на результатах оцінювання ризику для здоров'я, $\epsilon$ ефективним способом проведення спостереження за хворими групи факторів ризику, що піддаються корекції. В іншому випадку пропонуємо користуватися принизиами системи ідентифікаиії небезпеки. Підкреслимо, що ідентифікація небезпеки є не тільки початковим, але й ключовим етапом оцінювання ризику. На етапі ідентифікації небезпеки мають бути визначені граничні оцінки ризику.

Враховуючи виключну значимість етапу ідентифікації небезпеки, вважаємо доцільним проводити його в три етапи.

На першому проводиться оцінювання існуючих (визначених) факторів ризику.

Другий етап присвячується оцінюванню факторів ризику, що прогнозуються за даними моніторингу.

Третій - основний - полягає в зіставленні існуючих $\mathrm{i}$ прогнозованих факторів. Саме він дає можливість визначити валідність клінічних даних. Головним при цьому слід вважати ідентифікацію закономірностей першого та другого етапів шляхом зіставлення аналізу факторів ризику й інших показників здоров'я.

Активне виявлення захворювання незалежно від його клінічного плану, по суті, являє собою ідентифікацію невиявленого захворювання за допомогою тест-досліджень.
Взаємодія користувачів відбувається на базі застосування єдиної локально-обчислювальної мережі, що об'єднує всі підрозділі ЛПУ Кожний користувач, відповідно до посади, має унікальні права доступу до функціональних можливостей інформаційної системи та переліку даних (до яких він має право доступу).

Проект забезпечує інформаційну підтримку всіх основних процесів планування, реалізації та контролю виконання завдання щодо забезпечення повного циклу лікувально-профілактичних заходів у ЛПУ, серед яких виділяються основні:

1. Накопичення дільничними лікарям основних паспортних і медичних даних приписаного до дільниці населення.

2. Забезпечення роботи реєстратури 3 організації відвідувань пацієнтами лікарів-спеціалістів у поліклініках.

3. Реєстрація в інформаційній системі медичних записів, призначень і направлень пацієнтам, виконані лікарями-спеціалістами в поліклініках.

4. Планування госпіталізації пацієнтів, оперативне забезпечення процесу оформлення документації в приймальному відділенні стаціонару.

5. Формування електронної історії хвороби в стаціонарі, реєстрація оперативних втручань, лабораторних, діагностичних й інших досліджень, перелік використаних лікарських засобів, формування виписного епікризу.

6. Автоматизація роботи та реєстрація результатів досліджень лабораторій, діагностичних досліджень й інших параклінічних послуг, що надаються пацієнтам.

7. Накопичення статистичних даних, формування державної та відомчої звітності, аналіз результатів діяльності закладу.

8. Формування локальних медичних протоколів на основі медичних стандартів, шаблонів медикаментозного лікування згідно з Державним формуляром та забезпечення контролю їх виконання.

9. Інформаційне забезпечення функціонування адміністративних і допоміжних підрозділів ЛПУ.

10. Інформаційне забезпечення процесу проведення аналізу діяльності ЛПУ та фактичного використання бюджетних коштів.

Госпітальна інформаційна система має включати низку блоків програмних модулів та підсистем, що базуються на єдиній базі даних і забезпечують інформаційну підтримку всіх бізнес-процесів ЛПУ. Серед них виділяють, насамперед, адміністративні компоненти. До останніх відносяться система обліку кадрів; документообігу та контролю виконання розпоряджень; система управління лікарськими засобами та виробами медичного призначення тощо. 
Наступним структурним кластером є фінансово-економічні компоненти, що включають: систему бухгалтерського обліку та фінансового аналізу; планово-економічну підсистему; систему економіко-ста-тистичного аналізу діяльності закладу; систему розрахунку й аналізу БІЮ-груп; систему калькуляції вартості наданих медичних послуг.

Серед медичних компонентів розрізняють: систему обліку пацієнтів; систему реєстрації медичних послуг; систему управління реабілітацією та рекреацією пацієнтів; систему оброблення й аналізу медичної статистичної інформації.

Аналітичні й управлінські компоненти інформаційної системи для забезпечення оптимального прийняття рішень формуються 3 систем: управління ресурсами (СУР); управлінського обліку (СУО); управління якістю медичної допомоги (СУЯМД); оцінювання ризиків (СОР).

У результаті впровадження інформаційної системи керівники ЛІ ГУ мають можливість приймати більш збалансовані рішення на основі використання електронних карт пацієнтів, оцінювання ефективності використання бюджетних коштів; формування комплексу показників та інтегральної оцінки індикаторів діяль-

\section{Література} \\ 1. Алпатов А. П. Госпитальные информационные системы: \\ архитектура, модели, решения / А. П. Алпатов, Ю. А. \\ Прокопчук, В. В. Костра. - Днепропетровск : УГХ-ТУ 2005. - \\ $257 \mathrm{c}$. \\ 2. Гусев А. В. Информационные системы в здравоохране- \\ нии / Гусев А. В., Романов Ф. А., Дуданов И. П., Воронин А. \\ В. - Петрозаводск : ПетрГУ 2002. - 120 с.
}

ності ЛПУ; оцінювання рівня виконання медичних протоколів лікарями; динаміки показників якості лікування тощо.

Отже, принципи прийняття рішень у завданнях управління закладом будуються на забезпеченні моніторингу стану здоров'я пацієнта протягом усього його життя; створенні об'єктивної динамічної картини структури здоров'я населення 3 виділенням груп ризику і професійної діяльності; забезпеченні прийняття оперативних рішень у випадках невідкладних станів за рахунок отримання повної інформації про пацієнта; обгрунтування профілактичних й оздоровчих заходів.

Висновки. 1. Основним принципом побудови медичних інформаційних систем нового типу $є$ їх інтелектуалізація. Сучасні інформаційні медичні системи мають постійно працювати в режимах прийняття рішень, як у завданнях управління закладами охорони здоров 'я, так і в процесах діагностики та лікування захворювань.

2. Типові структури медичних інформаційних систем повинні мати можливості моніторингу ризиків для пацієнтів і рішення щодо ідентифікації небезпеки для управлінців.

3. Дуданов И. П. Информационная система в организации работы учреждений здравоохранения : практическое руководство / И. П. Дуданов, Ф. А. Романов, А. В. Гусев. -ПетрГУ - Петрозаводск, Издательство ПетрГУ 2005 - 238 с.

4. Медицинские информационные системы : теория и практика; под редакцией Г. И. Назаренко, Г. С. Осипова. - М. : ФИЗМАТЛИТ, 2005. - 320 с. 